9-1-2007

\title{
The Next Christendom: The Coming of Global Christianity
}

Philip Jenkins

jpj1@psu.edu

Follow this and additional works at: https://scholarsarchive.byu.edu/re

\section{BYU ScholarsArchive Citation}

Jenkins, Philip. "The Next Christendom: The Coming of Global Christianity." Religious Educator:

Perspectives on the Restored Gospel 8, no. 3 (2007). https://scholarsarchive.byu.edu/re/vol8/iss3/28

This Article is brought to you for free and open access by the Journals at BYU ScholarsArchive. It has been accepted for inclusion in Religious Educator: Perspectives on the Restored Gospel by an authorized editor of BYU ScholarsArchive. For more information, please contact scholarsarchive@byu.edu, ellen_amatangelo@byu.edu. 


\title{
The Next Christendom: The Coming of Global Christianity
}

\author{
Philip Jenkins
}

Philip Jenkins (jpj1@psu.edu) is the distinguished professor of history and religious studies at Pennsylvania State University. His book The Next Christendom: The Coming of Global Christianity won the 2003 Christianity Today Book Award, the Gold Medallion Book Award, and the Theologos Book Award for the best academic book. His remarks below are adapted from his speech at BYU on October 19, 2006.

I would like to begin with an example of not just a prophecy but a prophecy that is empirically verifiable. This seventeenth-century prophecy came from a Roman Catholic Saint by the name of St. Vincent De Paul, who, back in the year 1640, was looking at the violent world around him. It was a world in which Catholics were killing Protestants, Protestants were killing Catholics, and Christians were killing Jews. He observed that Jesus said that His Church would last until the end of time, but He never once mentioned the word Europe. The Church of the future will be the church of South America, the church of Africa, the church of China and Japan. ${ }^{1}$ And I suggest that this is perhaps as close as we can get to an empirically verifiable prophecy. We may disagree with the influence of Christianity in Japan, though Japan has produced some very fine Christian writers, but otherwise Christianity is moving decisively to the Global South, to those three parts of the world.

It would be very easy to tell this story in terms of overwhelming numbers, and there is a great temptation to bludgeon people with statistics and numbers. I don't want to do that, but some of these statistics really clamor for quotation to provide a rough framework of what's happening. In the world today, there are approximately two billion Christians. Of those, the largest contingent, about 530 million, 
live in Europe. Close behind is Latin America, with 510 million; Africa has about 390 million; and Asia has about 300 million. However, if we project that film forward into the future, the numbers change quite rapidly. By 2025, the title for the "most Christian" continent-the continent with the largest number of Christians-will be in competition between Africa and Latin America. ${ }^{2}$

If we move further into the future, however, there is no doubt that by about 2050, Africa will win. In terms of population distribution, Christianity will be chiefly a religion of Africa and the African Diaspora, which will, in a sense, be the heartland of Christianity. Let me give you one projection for the countries in the world that will have the largest Christian populations by the year 2050; and, as one might say in this context, I do not claim this as gospel, but it is plausible. Where will the largest Christian populations be in 2050? At the head of the list will still be Europe, followed in no particular order by Brazil, Mexico, Nigeria, the Congo, Ethiopia, the Philippines, and China.

If you ask older people, they might be able to tell you of something they remember from their youth called "western Christianity." Whether it still exists is a matter of some debate. If I ask you to think, for example, of a typical Roman Catholic, what do you think of? What does that person look like? Well, bear in mind a couple of figures. Last year there were more Roman Catholic baptisms in the Philippines than in France, Spain, Italy, and Poland combined. These days, countries like Nigeria, the Philippines, and Mexico are exporting priests to countries that used to be the great heartlands of Catholic Christianity. You can go to Ireland and meet Nigerian priests because there are not enough Irish priests.

If the change I am describing were just a change of ethnicity or geography, then it would be interesting. But I suggest to you that it is actually a much more important change because the character of that Christianity as it moves south is also changing substantially.

I do not claim there is such a thing as a southern Christianity. The Christianities of the Global South are very diverse, but they have certain things in common that are of great interest and great significance for a church like The Church of Jesus Christ of Latter-day Saints. This is because the kinds of Christianity that are succeeding across much of the Global South tend to be more traditional in their view of religious authority; they are charismatic in the sense of being open to ideas of dreams, prophecies, and visions; and they are deeply committed to ideas of healing. They are, in that sense, more supernaturally oriented.

We are already seeing some very telling gaps between northern and southern churches as numbers grow. For example, within the Anglican 
Communion, there is a very interesting shift. The American branch of the Anglican Communion is the Episcopal Church. It is a very liberal body. A couple of years ago it appointed an actively gay bishop, much to the horror of the churches of the Global South-especially those churches in Africa-who protested very strongly. ${ }^{3}$

The American Episcopal Church basically said, "Who are you to tell us this?" And the bishops of the Global South told them who they were to tell them this: "You in America, you have two million Episcopalians, and the number is going down fast. In Nigeria, back in 1975, we had five million Anglicans. Now we've got 20 million. It's going to be 35 million by 2025. Of course, we are not the largest, we are not the only big church in the Anglican Communion. No, no, no! There are lots of others. There's Uganda, there's Kenya. The heart of the Church has moved south like many other churches and denominations, and when some of those churches look at what their liberal brethren in the North are doing, they are very disturbed."

Some of the language in the Anglican debates has become very harsh. One recent statement from the Nigerian Church discussing the American Episcopal Church begins with the line, loosely quoted, "When a cancerous lump in the body has resisted all treatment, the time has come for it to be excised." Some feel this is lacking in Christian charity. However, when people in the Global North look at some of these comments, they assume that perhaps churches in the Global South are backward, uneducated, and primitive-they have this very fundamentalist approach. But I want to suggest something different. I want to suggest that there are reasons, not just for conversion to Christianity and for the spread of Christianity but also for the particular kinds of Christianity that are growing. In short, I want to suggest that there are many features and characteristics of the societies into which Christianity is moving that give people a special taste, a special liking, a special preference for the Bible.

When you read the Bible, when you read the scriptures in a way that makes it seem like your book, describing your society, your reality, then it tends to give scripture more moral force. You can no longer use the argument, for example, that many Americans might use: "Well, what it says in the Old Testament is interesting historically, but it just describes such a different world. What does it have to do with us today?" If you are in many parts of sub-Saharan Africa, it is exactly those parts of the Old Testament that have this kind of documentary relevance-where it seems to be describing your world-and so you tend to take the moral proscriptions very seriously. 
Let me give you some examples of this. First, I think for many American and European Christians, the Old Testament is a puzzling book; it is a distant book. It is a book that is hard to take seriously as a direct kind of instruction. In much of Africa and in much of Asia, the main danger with the Old Testament is that it has too much appeal. It is difficult to make the argument that it is, in a sense, superseded by the New Testament. Why? Think about it. Imagine trying to preach the Bible in a society that knows about things like nomadism, paganism, polygamy, and blood sacrifice and that regards these as familiar parts of life. Even if a sophisticated urban African does not know these things firsthand, he or she has relatives and neighbors who do know these things. The Old Testament, therefore, describes this kind of world. If a church speaks the lesson of prophecy as a continuing force, that is something that has great relevance in a society that takes prophecy seriously.

To take one example, much Evangelical Christianity is based on the idea of atonement - the atoning death of Christ. I think for many Americans the idea that blood is shed for sin is a puzzling and even repulsive doctrine. If you try to preach this message in Africa, however, you are speaking to a society where blood sacrifice is a familiar reality. For those people, sacrificing a sheep or a goat is a very well-known part of life.

When I talk to Evangelicals in this country, for example, we use terms like "power in the blood," and I'm often tempted to ask them, "Have you ever seen a blood sacrifice? Have you ever smelt a blood sacrifice?" The answer usually is no. But it does give a great deal of power. There's a great West African theologian by the name of Kwame Bediako who was doing a commentary on the letters of Paul, and he chose one letter particularly as being "Africa's epistle" because it reads as if it were written directly to and for Africans. It was the epistle to the Hebrews. You think, "Well, why is that?"

What is the epistle to the Hebrews? It is an epistle that is all about the rituals of the Jewish temple, the sacrifices, and the rituals of the priests in the temple, which, for many Americans and many denominations, are archaic and puzzling-it's a strange world.

But Africans know these ideas. When Africans read the book of Revelation and read about the altar, the lamb, the throne, and the blood, they relate because these are familiar things. These are things we know all about. So a large part of the message has already been conveyed. ${ }^{4}$

You get this very strongly if you look at hymns in the contemporary Global South. Let me make what may sound like a strange observation. We are today living in the greatest age of Christian hymn writing. More hymns are being composed now and being sung now, but most of them 
are not accessible to us as Americans because they're in languages we do not know. They are written in Yoruba; they are written in Luganda. Some of the stories of these hymns are just remarkable. ${ }^{5}$

One of the most powerful is called the "Tukutendereza Yesu," which is the great hymn of East African Christianity. The stories associated with this hymn are amazing. You hear stories, for instance, of African Christians who are on the point of being murdered by the forces of a hostile army. They will sing this hymn, and the soldiers about to kill them will join in before letting them go. This is a hymn of enormous power. What is it about? It is about the power in the blood. It is about atonement. It is about these ideas, which are Christian ideas, that carry such special weight for that kind of audience because they also speak to familiar, traditional ideas. ${ }^{5}$

I make another observation. As Christianity moves to the Global South, Christianity is also entering a world that is a very poor world. If you want to think of the average Christian in the world today, then think of, perhaps, a woman living in a village in Nigeria or in a favela (a shantytown in Brazil)—probably somebody who, by typical American standards, is inconceivably poor. When people like that read or hear the stories in the Gospels, they hear about a world that is so familiar to them-a world in which of course a poor woman who loses a coin is going to ransack the house trying to find it because that's all she has to pay for her kids' food that night.

Let me read you just one quick quote here from a novelist named Francisco Goldman, writing about Guatemala: "Guatemala certainly feels biblical. Sheep, swine, donkeys, serpents - these are everywhere, as are centurions, all manner of wandering false prophets, pharisees, lepers and whores. The poor, rural, mainly Mayan landscape has an aura of the miraculous. ... [ [It] is the perfect backdrop for religious parables about fields both barren and fertile, fruits and harvests, hunger and plenty."

When you read the scriptures through Third World eyes or when you read the scriptures through hungry eyes, you begin to realize some things. You begin to realize how much of the Bible is about food. Why? Well, because food is the most important thing in the world. If you want to convey a lesson, a metaphor, you do it in terms of food; you do it in terms of what John Lonsdale, a great African scholar, calls "the imagery of the belly."

If you want to talk about politics in the Global South, everything is in terms of a bite. A bribe is a bite and so on. ${ }^{8}$ This was brought home to me not long ago. I was talking to some West Africans about this point, and they said, "There are many things in the Bible which 
make great sense to us that perhaps don't make much sense to Americans." We came up with some obvious examples like the parable of the sower, and they said, "Oh, of course, the one which really carries all the weight is Psalm 126." This much-quoted scripture includes the famous line, "He who goes out weeping, carrying seeds to sow, will return with songs of joy, carrying sheaves with him" (NIV, Psalm 126:6). You sow in weeping; you reap in rejoicing. If you ever hear this scripture, it's quite often used in the context of a funeral, and it's associated with the idea of death and resurrection. But let me ask you, why do people sow in weeping? My West Africans had the answer. When Psalm 126 was composed, there had obviously been a famine, just like West Africa had two years ago. When there is a famine, you have a very limited amount of corn, and you have a choice: you can use the corn to make food to feed your children, or you can sow the seed corn and have it grow for next year. But to choose the second option, you literally have to take the corn out of the hands of your hungry children. So you sow in weeping, and then you rejoice when you bring home the sheaves. ${ }^{9}$

In many parts of the world, people ask, "How are you?" and the response is, "Oh, my children are hungry"-because that is the time of year that the planting cycle begins. So when you have this in mind, when you have this image of food, you begin to look back at the New Testament to see how much is written about food. When, for example, people wanted to convey the image of the day of the Lord, this immeasurable glorious time when God would rule, how would they convey that image? It will be such an amazing time. It will be like a great banquet, where everyone has enough to eat. Can you imagine such a setting? Or even in the words of Mary, in the Gospel of Luke, "[God] filled the hungry with good things," and the real bonus: "[He] has sent the rich away empty" (NIV, Luke $1: 53){ }^{10}$

How do you convey the reversal of the day of the Lord? Even the rich won't have enough to eat, but the poor will. I would like to offer you a grace from a Chinese house church, and like many things that you see in Global South Christianity, this is the sort of prayer that could have been uttered in the earliest days of the Christian church: "Today's food is not easy to come by. God gives it to us. . . God protects us so that we can have the next meal." that you can rely on the meal you have-what's on the table in front of you-but you cannot rely on the next meal.

Receiving the food from God is also associated with protection from other ills. The other thing you notice is just how much the Bible 
is conditioned by famine, by stories of famine. I think most of us today only see or read stories about famine; it is something that we maybe see in the news or read about in the newspaper.

Imagine living in societies where famine is a frequent occurrence. Why did Joseph's brothers go to Egypt? They had to-a time of famine arose. From such stories, we realize how much of the Bible is about famine.

One of the books of the Bible that is most beloved in Africa is the book of Ruth. Why is that? It's a story about a society that's being destroyed by famine, in which society has basically collapsed, in which the men have gone off to the city because they can, in which the women are left behind with the children so they can hold the society together, and in which society survives because people are loyal to each other as a result of familial obligations. ${ }^{12}$ I can't think for a moment why something like that would carry so much weight in Africa, where it carries such a documentary relevance.

When you look at the Bible through Global South eyes, you almost begin to see a different Bible. There are passages within the Bible that perhaps do not carry so much weight for an American audience or a European audience, but in Africa or Asia, they carry so much more weight. One scripture I have rediscovered in the last couple of years is the epistle of James. Now the Epistle of James is one of these works that shows up in all sorts of places.

I think of one very appropriate reference-which is, of course, the spiritual odyssey of Joseph Smith, beginning when he read that Bible verse from the first chapter of James about praying to God and seeking wisdom. James has all sorts of passages that lead people on strange courses in their lives.

James is also one of the main providers of sermon texts in African churches. In one verse particularly, James says, "Why, you do not even know what will happen tomorrow. What is your life? You are a mist that appears for a little while and then vanishes" (NIV, James 4:14).

You read this in America, you read this in Europe, and we think it an interesting philosophy. Now read this in an African church where the average age of the congregation is about twenty, where the pastor is this ancient, gray-bearded old man of maybe twenty-eight, and where the average age of death in the community is thirty-eight. Your life is a mist, and passages like those in James carry a lot of weight. ${ }^{13}$

A few years ago I heard a talk by an archbishop from central Africa. He described an interesting world, one which many Christians around the world would look at and say, "What a great situation!" $\mathrm{He}$ complained about being so overworked. He said, "It's terrible; every 
Sunday they will say to you, 'Archbishop, come along to our village; we want to consecrate a new church here.' You go along the road, and there are hundreds of people, and you go to this vast new church, and then they say, 'Archbishop, while you're in the area, can you consecrate another new church?'” The idea was that there are new churches springing up everywhere. He also said two other things. He said that none of his clergy had been paid in six months, and he also said that he had never yet presided over a funeral where there were fewer than twelve bodies. So combine the prevalence of poverty, sickness, and death with a level of church growth that would be astounding.

That mix of poverty and deep, passionate religion is very characteristic. James also provides a very good way of communicating between different religions. Why is this? Because Islam, Buddhism, and other religions also grew up in societies that shared many of the same conditions: poverty, hunger, and disease. In fact, James actually sounds very Muslim when translated. He even calls God compassionate and merciful, and if you ever deal with a Muslim society, you will hear this phrase, "If God wills" (Inshallah). If you ever fly on a Middle Eastern airline, they may announce, "The plane will be taking off in two minutes if God wills." That can bother you.

In the context of Buddhism, James has a unique power because he preaches this basic idea of transience: your life is a mist. Recently, an English publisher reprinted many books of the Bible and in each case included an introduction by a celebrity, author, novelist, actor, or religious figure-sort of pop-culture figures. One of the texts was the epistle of James. Whom did they get to write the introduction to the epistle of James? The Dalai Lama. He began by saying, "I don't know much about Christianity, I know a lot about Buddhism. This is fine Buddhism."

James has this very interesting quality. If you were to try to evangelize a community and if you could use only one part of scripture, one book, one text, what would it be? Many possibilities come to mind. But there are some evangelists in the field and some missionaries in the field who actually think, "Well, if you want to speak to people, let's look at something that describes their lives and builds on that." James carries a lot of weight.

One other very important area is the area of good and evil, and this is a matter in which Northern and Southern churches tend to be quite divided. Now, it's certainly not a straight North-South division, but for most liberal, mainline churches in the Global North, many of the passages in the New Testament-especially about demons and healings and exorcisms-are so irrelevant that they seem almost an 
embarrassment-they're just not part of what the churches pay attention to. Jim Wallis once said that cutting out references to "the poor" from the Bible leaves very little to the text. He's dead right. If you take references to angels and healings and exorcisms and demons out of the Bible, you're left with a pretty thin pamphlet. ${ }^{15}$ And this is a point that I think many Global South churches have taken very seriously. If you are interested in speaking about Christianity in the Global South, you have to speak to a world in which the world of demons and spirits and curses is taken absolutely seriously.

It has been said by a very sane and sober mission scholar, Andrew Walls, that the two biggest areas of difficulty for white churches in Africa are ancestors and witchcraft. Even to speak of those things is an embarrassment. In African communities, however, unless you address those subjects, you are not speaking languages of vital concern; and that's why people turn to the New Testament, which deals with very similar concepts. ${ }^{16}$ Andrew Walls once said, in effect, "If you want to see the Christian church of the second century in operation, you can basically do one of two things. You can either invent a time machine, or you can buy an air ticket to Africa, and the air ticket to Africa is less expensive." If you look at the prayers-and once again, the hymns that are coming out of not only contemporary Africa but also India, China, Korea-so many of them read as if they were written eighteen hundred years ago.

Let me give you one example. This is a hymn from contemporary transference of Africa: "Jesus Christ is Conqueror / By his resurrection he overcame death itself / By his resurrection he overcame all things / He overcame magic / He overcame amulets and charms / He overcame the darkness of demon possession / He overcame dread / When we are with him / We also conquer." ${ }^{17}$

That hymn could have been composed in the year 150; it was actually composed about 1970. You are probably aware of the fact that in American churches, many people are very embarrassed by the hymns that used to be popular a hundred years ago because the hymns were very patriarchal and very militaristic and aggressive, so people tried to change them to make them nicer.

Here is an example of a contemporary African hymn. I particularly like this because it's by a woman from Ghana, and when you listen to it, you can pick up the very gentle woman's touch in it: "If Satan troubles us / Jesus Christ / You who are the lion of the grasslands / You whose claws are sharp / Will tear out his entrails / And leave them on the ground / For the flies to eat." ${ }^{18}$ I'm glad we don't have any of these aggressive hymns! 
Demonology is credible for African and Asian Christians in a way in which it has not been for European Christians or American Christians for a long time. I once listened to a white American Adventist pastor tell of an experience he had in a South African Adventist church in an area where white faces were not normally seen. Surprised, the members asked him, "Why are you here? You're an ordained pastor? That's the best news we could have!" The word then went up to the minister carrying out the service, and he made this very happy announcement to the crowd: "My friends, I have wonderful news. Pastor Smith has come to visit us all the way from America, and I'm going to ask him to conduct tonight's exorcism." The pastor told me that he had only seen exorcisms in movies, but he thought that he did all right! ${ }^{19}$

African churches, Asian churches, and emerging churches believe in the healing of mind and body as a paramount goal. Any American or European church that fails to appreciate that has no business trying to censor them. I offer you one quote from a West African independent church sermon: "Why are we in this church? We are all here in this church because we have found healing here. But for this church, the great majority of us here assembled would not be alive today. That is the reason why we are here." Each denomination-Methodist, Presbyterian, Anglican, Catholic, any-takes these issues very seriously, or it does not survive as a denomination.

Let me tell you another story of another African church service. Hundreds of people were trying to squeeze into a building, but there wasn't room for them; and at this service a woman announced that she'd been healed from a spinal complaint. She wanted to testify. Other people stood up. One person said, "I've been healed of this." Another person said, "I've been healed of this."

It goes on and on until finally the deacon of the church, wanting to see the service end before next Sunday, said, "All right, no more individual testimonies. Show of hands: How many people have been healed of this sort of disease?"

Eighteen, nineteen.

"How many have been healed of this sort of disease?"

Four, six, eight.

What sort of church was this? A Roman Catholic church. You get the idea that things you might associate with one kind of denomination, one kind of church, are found across the spectrum.

All churches are healing churches, and that is not necessarily just in physical healing - it means emotional or spiritual healing, healing from substance abuse. Once again, one of the most quoted passages 
is the line from James about the church offering anointing and prayer for the sick. You will notice here that I am dealing with many concepts that are very familiar to this audience. I am talking about ideas of the temple, continuing prophecy, and ideas of healing. You just have to be in a different kind of mindset.

In the West, for example, very few of us believe in ancestral evil. Very few of us believe that our grandparents did something bad and that we are therefore being punished for their sins. This is a strange, superstitious idea. In large sections of Africa and Asia, that is a cardinal belief. In India, you have probably 150 million people who are consigned to the lowest caste and who are treated worse than black Americans were ever treated during the years of segregation-because of their conduct in previous lives. Now imagine people in a society like that reading the New Testament and reading about Jesus, who arrives and eats with anyone. Eating with someone is the guide to whom you prefer to mix with-He eats with anyone, mixes with anyone, and destroys ideas of caste. Imagine those stories being read by an audience of people who perhaps have had violence because they once wandered near a temple, never mind trying to go in it, for which they could be killed. It is only when you read something like that that you appreciate the radicalism, perhaps, of the Christian message. ${ }^{20}$

There are so many other passages to explore, but I come back to this idea about food. Food is so important because it decides who you are-whom you're allowed to eat with. If, for example, you're a highcaste person and you eat with somebody who is low-caste, your caste has been damaged. It has to be restored by rituals. Then look at a passage that people of India and Africa still read and tell each other about with disbelief-the story where Jesus is taking a rest and a Samaritan woman comes to the well and Jesus has a chat with her. We read this and think, "It's a nice story. It has a couple of nice angles to it."

Try to imagine reading that story in a society where what Jesus did is absolutely wrong at every point and what the woman did is something for which she could be killed. We have are no longer shocked by the radicalism of the scriptures, but members of African and Asian churches continue to be. When they get over their shock, they tend to express a new interest in this very radical religion called Christianity.

I want to offer you a poem by Longfellow. This is a poem called "The Sicilian's Tale: King Robert of Sicily." He imagines a medieval king, King Robert, who

On St. John's eve, at vespers, proudly sat And heard the priests chant the Magnificat, 
And as he listened, o'er and o'er again

Repeated, like a burden or refrain,

He caught the words, "Deposuit potentes

De sede, et exaltavit humiles;"

And slowly lifting up his kingly head

He to a learned clerk beside him said,

"What mean these words?" The clerk made answer meet,

"He has put down the mighty from their seat,

And has exalted them of low degree."

Thereat King Robert muttered scornfully,

"'Tis well that such seditious words are sung

Only by priests and in the Latin tongue;

For unto priests and people be it known,

There is no power can push me from my throne!"

And leaning back, he yawned and fell asleep,

Lulled by the chant monotonous and deep. ${ }^{21}$

Those words, "He has put down the mighty from their seat / And has exalted them of low degree," could be a motto for Global South Christianity, which has served to take people who were outside the traditional order, people who are marginalized, people who did not have the right to speak, and has given them-from the idea of sociologist David Martin - tongues of fire and the right to speak out. ${ }^{22}$

In America, people often think in terms of "liberation theology" as a secular, political attitude. Deliverance means healing and spiritual warfare. In Africa and Asia, the two are the same word. African and Asian churches preach deliverance and liberation, or they do not succeed. They speak messages of secular and spiritual liberation. That's a very radical message.

I was once talking with a very wealthy lady from the Episcopal Church who said: "In your books you tell this wonderful story of these hundreds of millions of Christians in Africa and Asia, and this new kind of Christianity that's spreading all over the world. It's so biblical, and it's so apostolic, and it's passionate-it's like the earliest days of Christianity. Tell me, as Americans, as Christians, as Episcopalians, what can we do to stop this?" She's right about the passionate spread of this new kind of Christianity! What I think they do have right in the Global South is that they see the scriptures for the radical message they contain. Maybe the challenge in the Global North is to try to see the same message. RE

\section{Notes}

1. See Philip Jenkins, Next Christendom: The Coming of Global Christianity (New York: Oxford University Press, 2002), 191-92. 
2. See Philip Jenkins, New Faces of Christianity: Believe the Bible in the Global South (New York: Oxford University Press, 2006), 9.

3. See Jenkins, New Faces of Christianity, 2-4.

4. See Jenkins, New Faces of Christianity, 55.

5. See Jenkins, New Faces of Christianity, 33, 56.

6. Francisco Goldman, as quoted in Jenkins, New Faces of Christianity, 69.

7. John Lonsdale, as quoted in Jenkins, New Faces of Christianity, 78.

8. See Jenkins, New Faces of Christianity, 78.

9. See Jenkins, New Faces of Christianity, 73.

10. See Jenkins, New Faces of Christianity, 78.

11. Jenkins, New Faces of Christianity, 78.

12. See Jenkins, New Faces of Christianity, 79-80.

13. See Jenkins, New Faces of Christianity, 75.

14. See Jenkins, New Faces of Christianity, 87-90.

15. See Jenkins, New Faces of Christianity, 98-99.

16. See Jenkins, The Next Christendom, 123-24.

17. Jenkins, New Faces of Christianity, 104.

18. Jenkins, New Faces of Christianity, 104.

19. See Jenkins, New Faces of Christianity, 105.

20. See Jenkins, New Faces of Christianity, 121, 136-38.

21. Henry Wadsworth Longfellow, Henry Wadsworth Longfellow: Poems and Other Writings (New York: Library of America, 200), 379.

22. See Jenkins, New Faces of Christianity, 177. 